\title{
ANTHROPOGENIC RADIOCARBON IN THE EASTERN IRISH SEA AND SCOTTISH COASTAL WATERS
}

\author{
F. H. BEGG ${ }^{1}$, G. T. $C O O K^{1}$, M. S. BAXTER ${ }^{2}$, E. M. SCOTT ${ }^{3}$ and MARTIN MCCARTNEY ${ }^{4}$
}

ABSTRACT. ${ }^{14} \mathrm{C}$ is produced as an activation product in nuclear reactors, and may be discharged to both the atmosphere and the marine environment during nuclear fuel reprocessing. In the $\mathrm{UK},{ }^{14} \mathrm{C}$ is discharged, under license, into the Eastern Irish Sea by the British Nuclear Fuels plc (BNFL) reprocessing plant at Sellafield, Cumbria, northwest England, and is then transported into Scottish coastal waters. We analyzed intertidal biota samples to determine the effect of these discharges. The specific activities of ${ }^{14} \mathrm{C}$ found in these samples indicate that the uptake and bioaccumulation of ${ }^{14} \mathrm{C}$ is dependent on the type of organism and its feeding behavior. Measured ${ }^{14} \mathrm{C}$ concentrations in mussels (Mytilus edulis) were higher than those in winkles (Littorina littorea), which were greater than those found in seaweed (Fucus spp.); maximum observed activities were $c a .7,5$ and 3.5 times the accepted current ambient level of $260 \mathrm{~Bq} \mathrm{~kg}^{-1} \mathrm{C}$, respectively. Annual Nori (Porphyra umbilicalis) samples were analyzed for their ${ }^{137} \mathrm{Cs},{ }^{241} \mathrm{Am}$ and ${ }^{14} \mathrm{C}$ contents; both the ${ }^{137} \mathrm{Cs}$ and ${ }^{241} \mathrm{Am}$ results correlated well with published Sellafield discharge data $(r=0.877$ and 0.918 , respectively), whereas there was no significant correlation between measured ${ }^{14} \mathrm{C}$ activities and the discharge record, indicating increased complexity in the chemical and biological behavior of ${ }^{14} \mathrm{C}$ or some discrepancy in the estimated discharge records.

\section{INTRODUCTION}

The natural equilibrium ${ }^{14} \mathrm{C}$ concentration in the atmosphere, and subsequently, the oceans, has been perturbed over the last century by large injections of both stable and radioactive isotopes of carbon. A decrease of 2-3\% due to fossil-fuel utilization by 1950 (Suess 1953, 1955) was overshadowed by inputs from nuclear weapons testing in the late 1950s and early 1960s (2.2-3.5 $\times 10^{17} \mathrm{~Bq}$ ) (Lassey, Manning \& O'Brien 1988; Taylor et al. 1990), from which time $\sim 80 \%$ of the excess atmospheric ${ }^{14} \mathrm{C}$ has been transferred to the surface and, ultimately, the deep oceans. Future inputs of anthropogenic ${ }^{14} \mathrm{C}$ will depend on the growth and waste-management policies of the nuclear power industry. Current potential production is thought to be $\sim 4 \times 10^{14} \mathrm{~Bq}$ of ${ }^{14} \mathrm{C}$ per year (Baxter, personal communication 1990; IAEA 1989), with $40 \%$ of this released directly into the atmosphere or the marine environment, and the remainder retained in the reactor until decommissioning. Many studies have been made on the likely discharges from nuclear establishments to the atmosphere (Kunz, Mahoney \& Miller 1974, 1975; Magno, Nelson \& Ellet 1975; Fowler et al. 1976; Moghissi \& Carter 1977; Davis 1979; Beninson 1984; Kunz 1985) and the associated radiological implications to both local and global populations (Killough \& Rohwer 1978; McCartney et al. 1986; McCartney 1987; McCartney, Baxter \& Scott 1988a, b).

Although only a small proportion of the total ${ }^{14} \mathrm{C}$ is discharged to the marine environment, ${ }^{14} \mathrm{C}$ can be important for studying both the spatial distribution of a pollutant from a point source and the chemical behavior and fate of carbon within a near-shore environment. Ultimately, we can see the return of anthropogenic ${ }^{14} \mathrm{C}$ to mankind via the marine food chain. Also, sources of anthropogenic ${ }^{14} \mathrm{C}$, such as Sellafield, in northwest England, offer a unique opportunity to study the carbon cycle in great detail on a local scale, with the potential for determining relative transfers and fluxes between the numerous global carbon reservoirs.

Although ${ }^{14} \mathrm{C}$ is produced in small quantities relative to other radionuclides, such as the fission products, ${ }^{90} \mathrm{Sr}$ and ${ }^{137} \mathrm{Cs}$, McCartney, Baxter and Scott (1988a) indicated that anthropogenic ${ }^{14} \mathrm{C}$ will

\footnotetext{
${ }^{1}$ Scottish Universities Research and Reactor Centre, East Kilbride, G75 0QU Scotland

${ }^{2}$ IAEA International Laboratory of Marine Radioactivity, Principality of Monaco, MC 98000

${ }^{3}$ Department of Statistics, University of Glasgow, Glasgow, G12 8QQ Scotland

${ }^{4}$ Ministry of Agriculture, Fisheries and Food, Directorate of Fisheries Research, Pakefield Road, Lowestoft, Suffolk

NR33 0HT England
} 
be radiologically significant on a global scale, delivering one of the highest collective effective dose equivalent commitments (CEDEC) to the global population, due to its long half-life and high mobility in the environment. Although discharge to the oceans reduces the dose slightly because of a longer residence time and, hence, more decay prior to human uptake (McCartney, Baxter \& Scott, 1988a), ${ }^{14} \mathrm{C}$ will remain a radiologically important nuclide produced by the nuclear industry, unless alternative waste-management policies are implemented.

During nuclear fuel reprocessing at Sellafield, ${ }^{14} \mathrm{C}$ is released both to the atmosphere as ${ }^{14} \mathrm{CO}_{2}$ $(\sim 90 \%)$ and into the Eastern Irish Sea $(\sim 10 \%)$ via low-level liquid effluent discharges. The chemical form of the marine discharge is unknown but is thought to be a carbonate. The Sellafield site has been in operation since 1952, but has routinely monitored the amount of ${ }^{14} \mathrm{C}$ discharged only since 1 January 1984 (British Nuclear Fuels plc (BNFL) 1985). Discharge data published prior to this date are best-estimate values.

In an attempt to determine the fate of Sellafield-derived ${ }^{14} \mathrm{C}$, we undertook a comprehensive study of the marine environment. We collected and analyzed a wide variety of samples, representing the biological and chemical forms present, to understand the processes occurring between them. Other areas of this study have focused on the distribution of ${ }^{14} \mathrm{C}$ in the water column, including the specific activities associated with the biogeochemical fractions (Begg et al. 1991). We are also studying phytoplankton, bottom-dwelling fish and intertidal and bottom sediments to determine the fate of Sellafield-derived ${ }^{14} \mathrm{C}$. We focus here on the intertidal biota samples, and aim to answer three main questions:

1. Whether the study of intertidal biota and their utilization of different carbon pools as a source of nutrients can help determine the form of the ${ }^{14} \mathrm{C}$ discharged from Sellafield. Although our samples could also be used to calculate the possible radiological hazard to local populations consuming shellfish from the vicinity of Sellafield, our major goal is to understand the chemistry and cycling of this anthropogenic ${ }^{14} \mathrm{C}$.

2. To measure the geographical extent of the transport of Sellafield-derived ${ }^{14} \mathrm{C}$ from the discharge location, using the selected organisms as indicators of the levels of ${ }^{14} \mathrm{C}$ either dissolved in the water column or as particulate material.

3. Whether previously estimated discharge data could be validated from a series of Nori (Porphyra umbilicalis) samples collected between 1967 and 1988. This would provide a more accurate record of past inputs into UK coastal waters and perhaps could be used in future mathematical models.

\section{MATERIALS AND METHODS}

\section{Organism Selectivity as a Guide to the Chemical Form of Sellafield-Derived ${ }^{14} \mathrm{C}$}

We collected three organism types, mussels (Mytilus edulis), winkles (Littorina littorea) and seaweed (Fucus spp.), from 19 sites on a coastal transect from Earnse Point, $40 \mathrm{~km}$ south of Sellafield, north to Inverkip in the Clyde Sea area (Fig. 1), from November 1988 to February 1989. Mussels are filter feeders that retain particulate matter from the water column; winkles graze particulate matter deposited by seawater on large seaweeds and algae-covered rocks, whereas during photosynthesis, seaweed can directly utilize the inorganic carbon that is dissolved in the seawater. It is also feasible for seaweed to use atmospheric carbon during periods of low water.

Intra-site differences in ${ }^{14} \mathrm{C}$ concentrations between these species will reflect the specific activity of the carbon reservoirs that are the main sources of carbon for biological uptake; mussels will reflect the level of ${ }^{14} \mathrm{C}$ associated with the particulate matter suspended in the water column, where- 


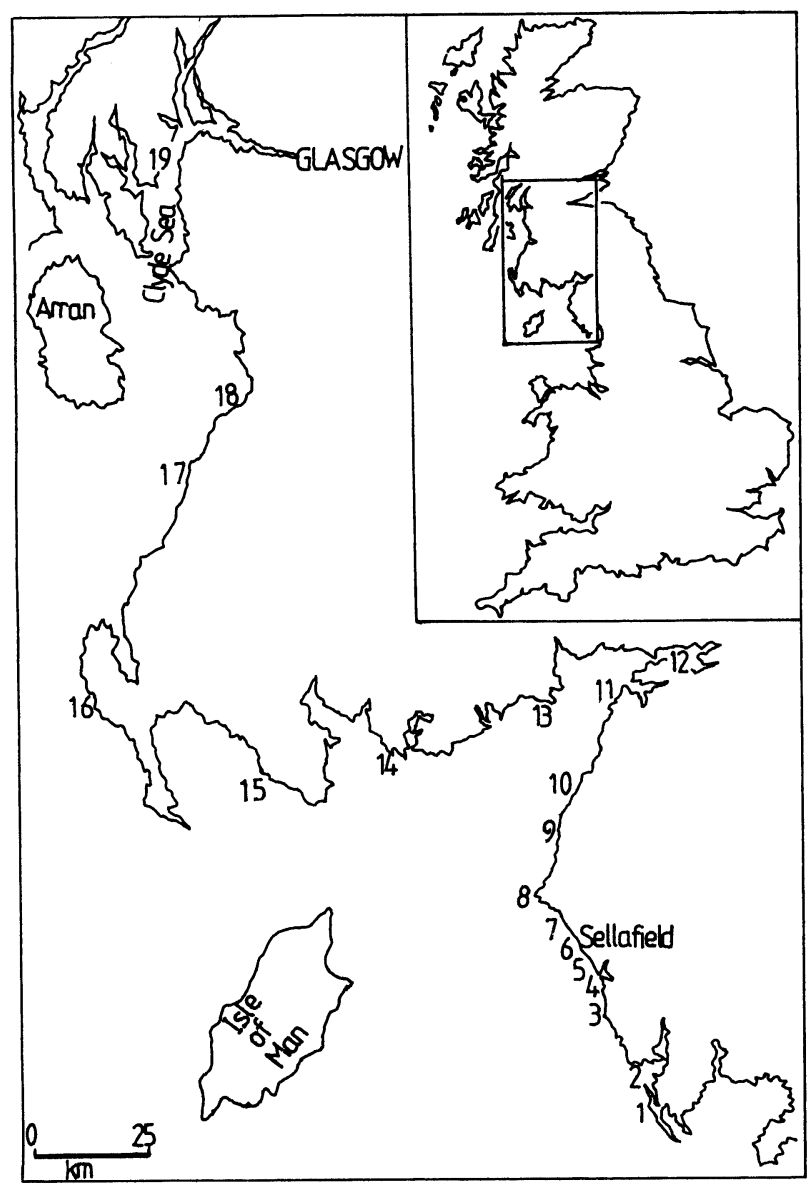

Fig. 1. Map of the study area showing the locations selected for intertidal biota sample collection November 1988-February 1989

as winkles will reflect the concentration of ${ }^{14} \mathrm{C}$ in the particulate matter deposited on surfaces by the surrounding water together with some seaweed-derived activity. Specific activities in seaweed should reflect those in the dissolved inorganic carbon (DIC) phase of seawater.

To complete this study, samples of shell material from both mussels and winkles from selected sites were also analyzed for their ${ }^{14} \mathrm{C}$ activity. Tanaka, Monaghan and Rye (1986) showed that $23-68 \%$ of molluscan shell material derived from metabolic carbon rather than DIC in the water column. Hence, Sellafield-derived ${ }^{14} \mathrm{C}$ should be incorporated into the shells of mollusks growing in the vicinity, and their specific activity will reflect the ${ }^{14} \mathrm{C}$ concentrations of both the surrounding DIC and that accumulated by the organism.

\section{Spatial Distribution of Sellafield-Derived ${ }^{14} \mathrm{C}$}

Biota samples for the determination of organism selectivity were collected over an extensive geographical area to assess the spatial distribution of Sellafield-derived ${ }^{14} \mathrm{C}$. We felt that this, in turn, would help us determine the chemical form of the ${ }^{14} \mathrm{C}$ during transport and the general behavior of carbon in the coastal marine environment.

\section{Temporal Distribution of Sellafield-Derived ${ }^{14} \mathrm{C}$}

BNFL started monitoring and quantifying their discharges of ${ }^{14} \mathrm{C}$ from Sellafield in 1984. In an attempt to evaluate the release of ${ }^{14} \mathrm{C}$ to the Eastern Irish Sea prior to this date, the Ministry of 
Agriculture, Fisheries and Food, Lowestoft (MAFF) submitted for analysis a suite of Nori samples collected at Seascale (2 $\mathrm{km}$ south of Sellafield) from 1967-1988, as part of their aquatic monitoring program. These samples were also analyzed for ${ }^{137} \mathrm{Cs}$ and ${ }^{241} \mathrm{Am}$ to ascertain whether they reflected the discharges associated with Sellafield. ${ }^{137} \mathrm{Cs}$ and ${ }^{241} \mathrm{Am}$ were selected, as both are anthropogenic (Sellafield being the only major source in this area), and exhibit two extreme forms of behavior in the water column $-{ }^{137} \mathrm{Cs}$ is known to be conservative and remain in the water column (Pierson 1988), whereas ${ }^{241} \mathrm{Am}$ is very particle-reactive and accumulates in areas of active sedimentation (Mackenzie, Scott \& Williams 1987; McDonald et al. 1990).

\section{Sample Analysis Procedures}

In the laboratory, we separated mussel and winkle flesh from the shells. The flesh and seaweed samples were then washed in $0.5 \mathrm{M} \mathrm{HCl}$ to remove any extraneous carbonate material from their surfaces, rinsed in distilled water and dried to a constant weight at $60^{\circ} \mathrm{C}$. For ${ }^{14} \mathrm{C}$ analysis, a representative $15-20 \mathrm{~g}$ of each sample were combusted in an oxygen-rich atmosphere in a highpressure combustion vessel, as described by Barker, Burleigh and Meeks (1969). The resultant $\mathrm{CO}_{2}$ was collected and converted to benzene, for liquid scintillation counting (LSC), via lithium carbide and acetylene (Barker 1953). The shell underwent an initial controlled hydrolysis to remove the outer $20 \%$ prior to ${ }^{14} \mathrm{C}$ analysis, to remove any extraneous material. The remaining material was hydrolyzed using $4 \mathrm{M} \mathrm{HCl}$ and, again, the resulting $\mathrm{CO}_{2}$ was converted to benzene for LSC. When received from MAFF, the Nori samples were already dried and ground. Prior to combustion for ${ }^{14} \mathrm{C}$ analysis, $25 \mathrm{~g}$ of each sample were counted on a high-resolution reverse electrode germanium (HpGe) detector for the $\gamma$-ray emitting radionuclides, ${ }^{137} \mathrm{Cs}$ and ${ }^{241} \mathrm{Am}$.

\section{RESULTS AND DISCUSSION}

All ${ }^{14} \mathrm{C}$ concentrations are reported as specific activities $\left(\mathrm{Bq} \mathrm{kg}^{-1} \mathrm{C}\right)$, corrected for fractionation, relative to the international standard, NBS Oxalic Acid II. $\delta^{13} \mathrm{C}$ values are determined relative to the international PDB standard used in all carbon isotope studies and are quoted as per mil (\%o) differences from the standard. The biota sample results are also shown as $\Delta^{14} \mathrm{C}$ values in the figures. The current accepted ambient ${ }^{14} \mathrm{C}$ concentration in the atmosphere is $260 \mathrm{~Bq} \mathrm{~kg}{ }^{-1} \mathrm{C}$, and although surface oceans are widely considered to have only $96 \%$ (NCRP 1985) of the atmospheric specific activity (due to differences in the rates of uptake and loss of ${ }^{12} \mathrm{CO}_{2},{ }^{13} \mathrm{CO}_{2}$ and ${ }^{14} \mathrm{CO}_{2}$ across an air/water boundary), biota samples collected on the northwest coast of Scotland, where no anthropogenic inputs of ${ }^{14} \mathrm{C}$ occur, suggest that a baseline value of $260 \mathrm{~Bq} \mathrm{~kg}^{-1} \mathrm{C}$ is realistic for this study of the environmental impact of Sellafield-derived ${ }^{14} \mathrm{C}$ on the marine system.

\section{Organism Selectivity as a Guide to the Chemical Form of Sellafield-Derived ${ }^{14} \mathrm{C}$}

All the biota samples analyzed to date have shown ${ }^{14} \mathrm{C}$ concentrations above the baseline value of $260 \mathrm{~Bq} \mathrm{~kg}^{-1} \mathrm{C}$ (Table 1). Figure 2 illustrates the ${ }^{14} \mathrm{C}$ concentrations found in the three sample types collected at the sites closest to Sellafield (locations 1-13). It is immediately apparent that the level of ${ }^{14} \mathrm{C}$ present in the organic material is greatly influenced by the type of organism analyzed.

At each site, mussels consistently showed the highest observed specific activities and seaweeds the lowest. This trend diminishes somewhat with distance from the point of discharge, as all three sample types appear to reach a common activity of $275-280 \mathrm{~Bq} \mathrm{~kg}^{-1} \mathrm{C}$ at the sampling sites farther north within the Clyde Sea area. This common activity is not observed at the southerly sampling stations, where organism selectivity is still apparent. Extrapolation of Figure 2 would indicate that a common specific activity would be obtained if the sampling transect was extended to $50-60 \mathrm{~km}$ from Sellafield. 
TABle 1. Specific Activities ( $\mathrm{Bq} \mathrm{kg}{ }^{-1} \mathrm{C} \pm 1 \sigma$ ) Measured in Coastal Biota Samples

\begin{tabular}{lllllc}
\hline \multirow{2}{*}{$\begin{array}{l}\text { Site } \\
\text { no. }\end{array}$} & Location & Distance & \multicolumn{2}{c}{ Specific Activity } & $\left(\mathrm{Bq} \mathrm{kg}^{-1} \mathrm{C} \pm 1 \mathrm{\sigma}\right)$ \\
\cline { 3 - 5 } & Mussels & Winkles & Seaweed \\
\hline 1 & Earnse Point & $37.8 \mathrm{~km}$ South & $601.15 \pm 2.00$ & $501.28 \pm 1.88$ & $352.95 \pm 1.54$ \\
2 & Haverigg & $30.3 \mathrm{~km}$ South & NA & NA & $356.66 \pm 1.61$ \\
3 & Annaside & $19.8 \mathrm{~km}$ South & NA & NA & $433.28 \pm 1.87$ \\
4 & Ravenglass & $10.8 \mathrm{~km}$ South & $1542.91 \pm 5.94$ & $\mathrm{NA}$ & $756.41 \pm 3.43$ \\
5 & Drigg & $6.5 \mathrm{~km}$ South & $1708.73 \pm 4.93$ & $1386.22 \pm 4.44$ & NA \\
6 & Sellafield & 0 & $1779.10 \pm 6.58$ & $983.68 \pm 4.23$ & $937.42 \pm 3.38$ \\
7 & Nethertown & $5 \mathrm{~km}$ North & $1412.62 \pm 4.20$ & $988.42 \pm 4.66$ & $527.35 \pm 3.41$ \\
8 & St. Bees & $10.2 \mathrm{~km}$ North & NA & NA & $469.61 \pm 1.45$ \\
9 & Workington & $30 \mathrm{~km}$ North & NA & $453.32 \pm 2.17$ & $343.33 \pm 2.20$ \\
10 & Maryport & $38.5 \mathrm{~km}$ North & NA & NA & $331.20 \pm 2.02$ \\
11 & Silloth & $52 \mathrm{~km}$ North & NA & NA & $325.47 \pm 1.18$ \\
12 & Bowness-on-Solway & $58 \mathrm{~km}$ North & NA & NA & $286.55 \pm 3.38$ \\
13 & Rockcliffe & $77 \mathrm{~km}$ North & $449.04 \pm 1.89$ & $330.80 \pm 1.28$ & $297.81 \pm 1.08$ \\
14 & Auchenlarie & & $401.07 \pm 1.57$ & $348.24 \pm 1.30$ & $311.23 \pm 1.71$ \\
15 & Port William & & NA & NA & $314.91 \pm 1.25$ \\
16 & Port Patrick & & NA & NA & $281.91 \pm 1.06$ \\
17 & Girvan & $281.96 \pm 1.30$ & NA & $283.75 \pm 1.06$ \\
18 & Ayr & $272.48 \pm 0.94$ & $280.69 \pm 1.25$ & $274.87 \pm 0.96$ \\
19 & Inverkip & $281.96 \pm 1.30$ & $280.18 \pm 1.10$ & $272.99 \pm 1.16$ \\
\hline
\end{tabular}

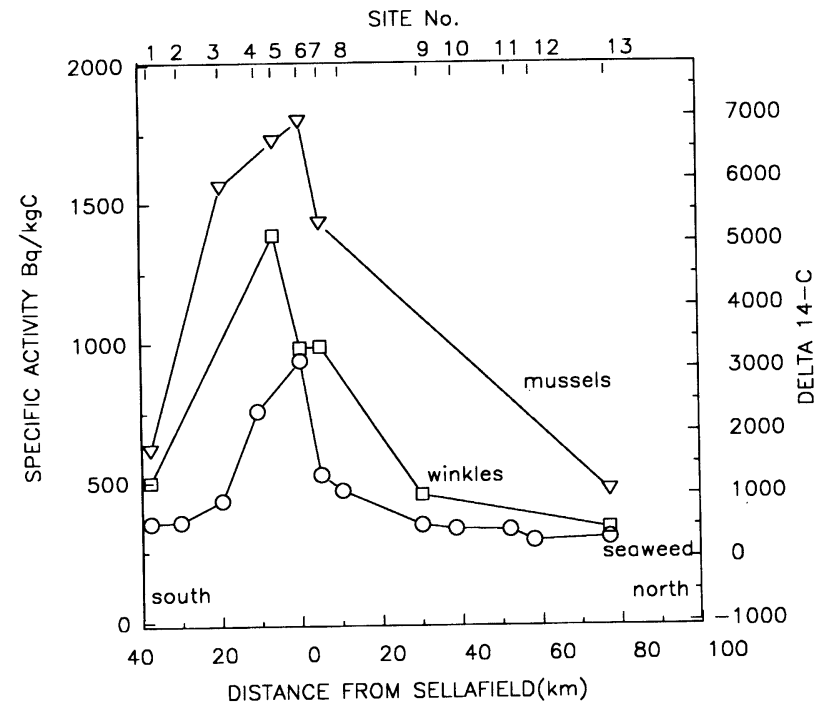

Fig. 2. Specific activities measured in biota samples collected along a coastal transect in the immediate vicinity of Sellafield

The highest observed specific activities for mussels $\left(1779 \mathrm{~Bq} \mathrm{~kg}^{-1} \mathrm{C}\right)$ and seaweed $\left(937 \mathrm{~Bq} \mathrm{~kg}^{-1}\right.$ C) were found at Sellafield, whereas that for winkles $\left(1386 \mathrm{~Bq} \mathrm{~kg}^{-1} \mathrm{C}\right)$ was found $6.5 \mathrm{~km}$ to the south at Drigg. These values correspond to specific activities $\mathrm{ca}$. 7, 3.5 and 5 times the accepted current baseline value of $260 \mathrm{~Bq} \mathrm{~kg}^{-1} \mathrm{C}$, and indicate some degree of organism selectivity occurring in the uptake of anthropogenic ${ }^{14} \mathrm{C}$ due to differences in feeding behavior. ${ }^{14} \mathrm{C}$ enhancements were also found in both mussel and winkle shells, but these were less than those found in the 
corresponding organic matter, e.g., $1207 \mathrm{~Bq} \mathrm{~kg}^{-1} \mathrm{C}_{\text {inorg }}$ and $1779 \mathrm{~Bq} \mathrm{~kg}^{-1} \mathrm{C}_{\text {org }}$ in Sellafield mussels, $1100 \mathrm{~Bq} \mathrm{~kg}^{-1} \mathrm{C}_{\text {inorg }}$ and $1386 \mathrm{~Bq} \mathrm{~kg}^{-1} \mathrm{C}_{\text {org }}$ in Drigg winkles. The lower activity in the inorganic matter may reflect the fact that the shell carbon accumulates throughout the entire lifespan of the organism, whereas the organic tissue is subject to turnover at a rate that is organism-specific. Tanaka, Monaghan and Rye (1986) found that the mollusk shells reflected the incorporation of metabolic organic carbon in conjunction with uptake of DIC from the water column. Hence, this may also explain the differences found between the inorganic and organic carbon specific activities in our samples. From these results, it appears that the discharges of ${ }^{14} \mathrm{C}$ from Sellafield are mainly, if not solely, in a dissolved inorganic form, which can be taken up by biota in the vicinity and incorporated into both the inorganic shell and the organic flesh of the organism. Further analyses on biogeochemical phases of the water column support this interpretation, as enhancements of ${ }^{14} \mathrm{C}$ are not found in either the dissolved or particulate organic carbon fractions, but levels above the current ambient background are observed in the DIC fraction (Begg et al. 1991).

From 1952 to 1984, when actual discharges were monitored, ${ }^{14} \mathrm{C}$ discharges from Sellafield have appeared to be relatively constant (R. Atherton, personal communication 1988). Thus, differences in the lifespans of the three biota types are unlikely to be major contributory factors to the observed activity trends. Hence, the results indicate that the specific activity of ${ }^{14} \mathrm{C}$ in the particulate phase of the water column must be higher than that in the DIC. We have found no evidence of this during the study of the biogeochemical phases in the water column (Begg et al. 1991). However, the water samples were collected in December 1989 during a winter sampling cruise, and the source of ${ }^{14} \mathrm{C}$-enriched particulate matter may be seasonally dependent, i.e., phytoplankton that photosynthesize in the general Sellafield area during the summer months. Although the observed specific activities in the DIC $\left(268-575 \mathrm{~Bq} \mathrm{~kg}^{-1} \mathrm{C}\right)$ do not approach those found at corresponding sites in the mollusks, one must remember that the water was sampled and analyzed at one time only, whereas the biota represent an integrated accumulation throughout their lifetimes.

\section{Spatial Distribution of Sellafield-Derived ${ }^{14} \mathrm{C}$}

The effect of ${ }^{14} \mathrm{C}$ discharges from Sellafield can be seen as far north as the Clyde Sea area, although the interorganism variation is negligible. Figure 2 shows the results obtained for the three organisms collected from $40 \mathrm{~km}$ south to $80 \mathrm{~km}$ north, indicating that, although the highest levels are found in the immediate vicinity of Sellafield, movement of the radionuclide does occur both to the north and south of the release point. For mussels and seaweed, the specific activities sharply decrease directly to the north of Sellafield - much more obviously than to the south - indicating that the transport of ${ }^{14} \mathrm{C}$ in the water column reflects the predominant residual surface currents in the area. These tend to follow the coastline south before turning to flow northward out of the Eastern Irish Sea via the North Channel (Dickson \& Boelens 1988). In the case of winkles, where the maximum activity is found south of Sellafield, this mirroring of the local currents is more pronounced, although more sampling locations need to be considered to determine the rate of decline in activity to the south. This similarity in distribution points to a common source of ${ }^{14} \mathrm{C}$ for all three organisms within the study area.

We considered two parameters in an attempt to model empirically this observed variation, namely, the distance and direction from the point of release. For the mussels and winkles, >90\% of the observed variation could be explained in terms of distance alone. For seaweed, the concentrations were best explained when both distance and direction were taken into account, which may indicate the use of atmospheric $\mathrm{CO}_{2}$ during periods of low water. 


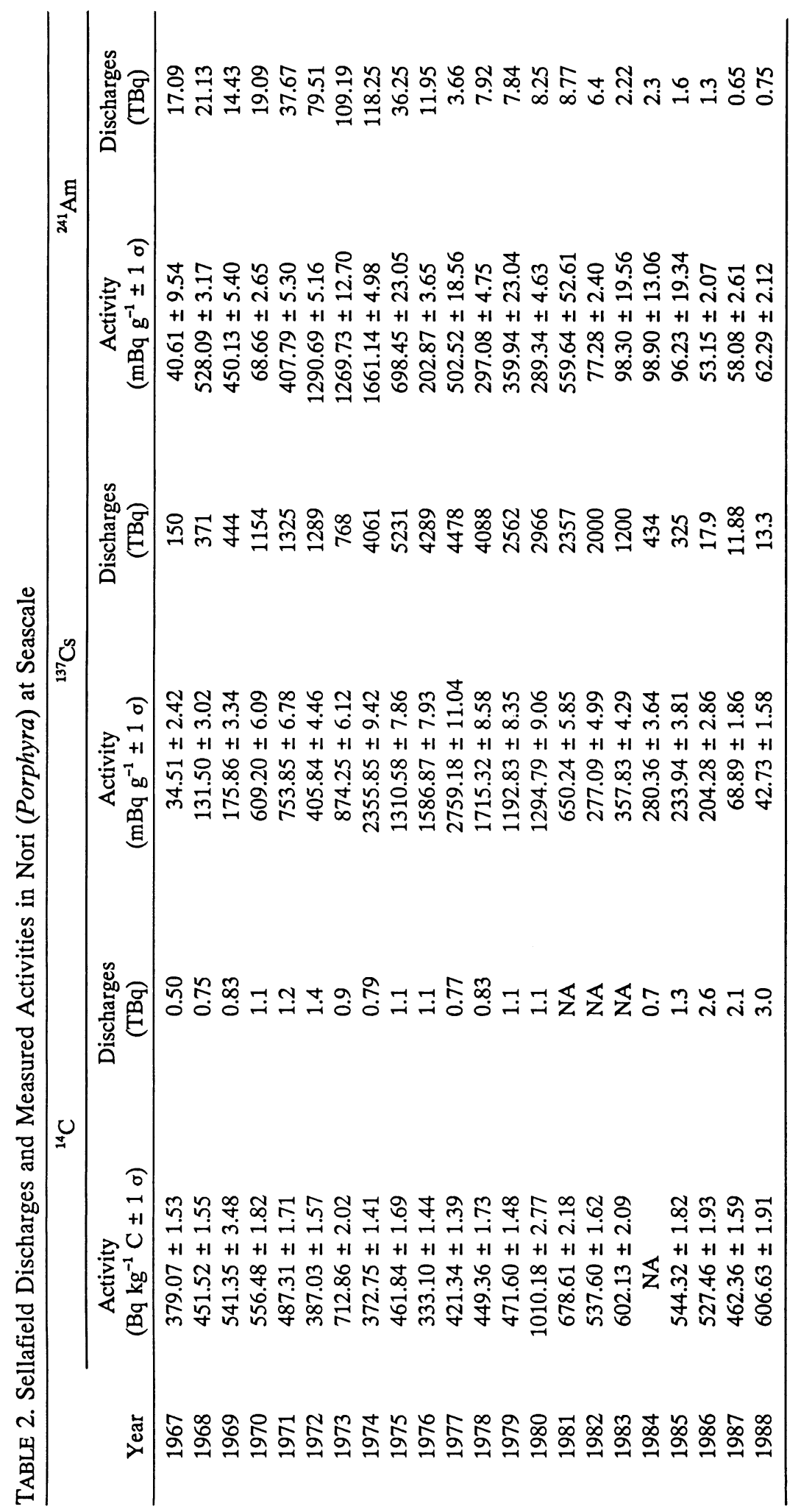




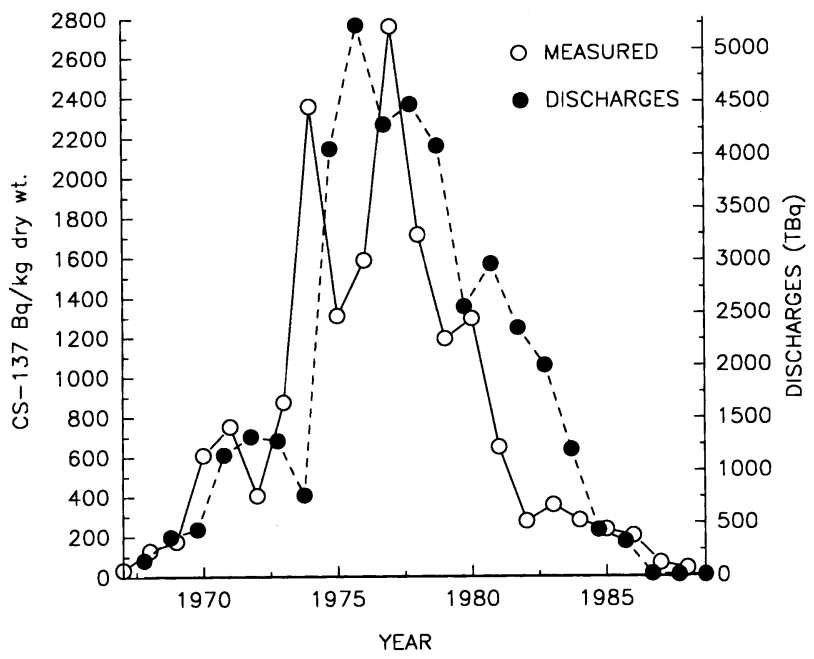

Fig. 3A. ${ }^{137} \mathrm{Cs}$ activities in the annual Porphyra samples collected at Seascale 1967-1988 shown with the published ${ }^{137} \mathrm{Cs}$ discharge data from Sellafield

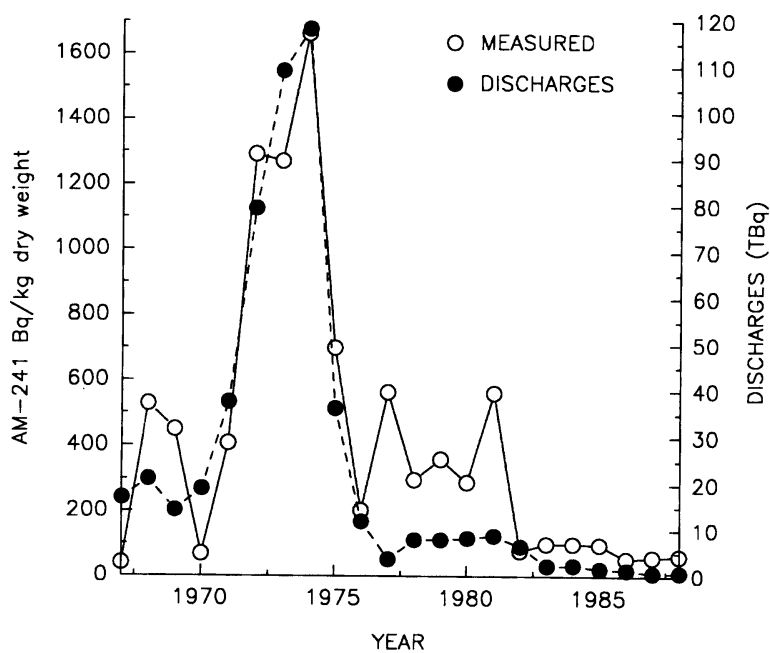

Fig. 3B. ${ }^{241} \mathrm{Am}$ activities measured in the annual Porphyra samples collected at Seascale 1967-1988 shown with the published ${ }^{241} \mathrm{Am}$ discharge data from Sellafield

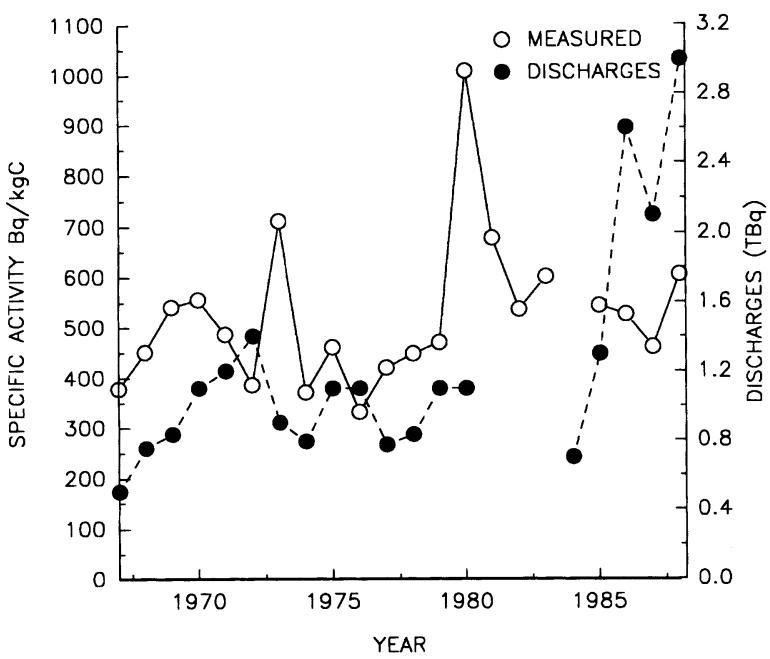

Fig. $3 \mathrm{C} .{ }^{14} \mathrm{C}$ specific activities measured in the annual Porphyra samples collected at Seascale 1967-1988 shown with the published ${ }^{14} \mathrm{C}$ discharge data from Sellafield 


\section{Temporal Distribution of Sellafield-Derived ${ }^{14} \mathrm{C}$}

Sellafield discharges a wide variety of both activation and fission products that have no natural production pathway and exhibit a varied pattern of chemical behavior. We measured two such anthropogenic radionuclides, ${ }^{137} \mathrm{Cs}$ (conservative) and ${ }^{241} \mathrm{Am}$ (particle-reactive), to determine the suitability of the chosen samples for a temporal study. Both have shown excellent agreement between the published discharge data and the activities measured using $\gamma$-ray spectroscopy (Table 2; Figs. 3A, B). The correlation coefficients ( $\mathrm{r}$ ) obtained for the measured activities and their relevant discharge data were 0.877 and 0.918 , respectively, which indicate that the Nori samples significantly reflect the levels of discharge in any given year for these particular nuclides.

Figure $3 \mathrm{C}$ illustrates the relationship observed between the ${ }^{14} \mathrm{C}$ specific activities as measured in the Nori samples and the discharge data released by BNFL. The correlation coefficient obtained in this case $(r=0.153)$ is not significant, which precludes these samples from being used to reconstruct the discharge record of ${ }^{14} \mathrm{C}$ into the marine environment from Sellafield.

Inclusion of influences from the atmosphere and hence, the bomb-produced ${ }^{14} \mathrm{C}$, over this time period does not improve the correlation coefficient, but problems still arise in matching the observed activities to the published discharge data. Previous work has shown that the activities measured in seaweed are considerably greater than those measured in the DIC fraction of the water column (Begg et al. 1991), indicating a bio-accumulation effect, which is likely to overshadow small variations resulting from differences in the levels of discharge.

To minimize seasonality effects, all samples were collected from March through June in each year. However, there is no information on the regularity or timing of ${ }^{14} \mathrm{C}$ discharges. Because ${ }^{14} \mathrm{C}$ is obviously much more "biologically involved" than either ${ }^{137} \mathrm{Cs}$ or ${ }^{241} \mathrm{Am}$, the seasonality of the discharges may be more important and, thus, could partially account for the poor correlation.

\section{CONCLUSIONS}

Biota samples from an area $40 \mathrm{~km}$ south of Sellafield northwards into the Clyde Sea are enriched in ${ }^{14} \mathrm{C}$. A common activity $15-20 \mathrm{~Bq} \mathrm{~kg}^{-1} \mathrm{C}$ above the accepted baseline value is reached at sites farthest from Sellafield. Despite the fact that the activities in mussels (exclusively filter feeders) are the highest, we found no evidence of enriched particulate carbon in the water column (Begg et al. 1991). This suggests that the particulate matter is seasonal, i.e., phytoplankton, and work is now in progress to obtain and analyze such material. Of course, we do not rule out the possibility that some of the Sellafield discharge is in the form of particulate carbon, although it appears that most of the discharged ${ }^{14} \mathrm{C}$ enters the DIC phase of the water column.

Although both ${ }^{137} \mathrm{Cs}$ and ${ }^{241} \mathrm{Am}$ measured in annually collected Nori showed excellent correlations with published Sellafield discharges, no such correlation was observed with ${ }^{14} \mathrm{C}$, thus precluding the use of these samples to help reconstruct past ${ }^{14} \mathrm{C}$ discharges. This is likely to be a reflection of the more complex biological involvement of ${ }^{14} \mathrm{C}$ rather than discrepancies in the reported discharge data, although the latter cannot be totally ruled out.

\section{ACKNOWLEDGMENTS}

We would like to thank MAFF for supplying, and Joe Toole for helping in the $\gamma$-spectroscopy analysis of the Nori samples, and Philip Naysmith for assistance in the ${ }^{14} \mathrm{C}$ analysis. One of us (F.H.B.) would like to thank The Natural Environment Research Council for funding this project. 


\section{REFERENCES}

Barker, H. 1953 Radiocarbon dating: Large-scale preparation of acetylene from organic material. Nature 172: 631-632.

Barker, H., Burleigh, R. and Meeks, N. 1969 New method for the combustion of samples for radiocarbon dating. Nature 221: 49-50.

Begg, F. H., Baxter, M. S., Cook, G. T., Scott, E. M. and McCartney, M. 1991 Anthropogenic ${ }^{14} \mathrm{C}$ as a tracer in western U.K. coastal waters. In Kershaw, P. J. and Woodhead, D. S., eds., Radionuclides in the Study of Marine Processes. London, Elsevier Applied Science: 52-60.

Beninson, D. J. 1984 Production, release and means of control of C-14 in heavy water reactors. Report to IAEA's Coordinated Research Programme on Carbon-14 from Nuclear Facilities. Vienna, IAEA, Contract 3247/R2/CF.

British Nuclear Fuels plc 1985 Annual report on radioactive discharges and monitoring of the environment 1984.

Davis, W., Jr. 1979 Carbon-14 production in nuclear reactors. In Carter, A. A. and Kahn, B., eds., Management of Low-Level Radioactive Waste. Oxford, Pergamon Press: 151-191.

Dickson, R. R. and Boelens, R. G. V., eds. 1988 The status of current knowledge of anthropogenic influences in the Irish Sea. International Council for the Exploration of the Sea (Denmark). Co-operative Research Report 155.

Fowler, T. W., Clark, R. L., Gruhlke, J. M. and Russel, J. L. 1976 Public health considerations of carbon-14 discharges from the light-water-cooled nuclear power industry. US Environmental Protection Agency Report. ORP-TAD-76-3. Springfield, Virginia, NTIS.

IAEA 1989 IAEA Bulletin 31(1) Quarterly Journal of the IAEA, Vienna.

Killough, G. G. and Rohwer, P. S. 1978 A new look at the dosimetry of ${ }^{14} \mathrm{C}$ released to the atmosphere as carbon dioxide. Health Physics 34: 141-59.

Kunz, C. O. $1985{ }^{14} \mathrm{C}$ discharges at three light water reactors. Health Physics 49: 25-35.

Kunz, C. O., Mahoney, W. E. and Miller, T. W. 1974 Carbon-14 gaseous effluent from pressurised water reactors. In Population Exposures, Proceedings of the 8th Midyear Topical Symposium of the Health Physics Society. US Atomic Energy Commission Report CONF-4018. Springfield, Virginia, NTIS: 229-234.

1975 Carbon-14 gaseous effluents from boiling water reactors. Transactions of the American Nuclear Society 21: 91-92.

Lassey, K. R., Manning, M. R. and O'Brien, B. J. 1988 Assessment of the inventory of carbon-14 in the oceans: An overview. In Inventories of Selected Radionuclides in the Oceans. IAEA, Vienna, IAEA. TECDOC-481.
Mackenzie, A. B., Scott, R. D. and Williams, T. M. 1987 Mechanisms of northwards dispersal of Sellafield waste. Nature 329: 42-45.

Magno, P. J., Nelson, C. B. and Ellet, W. H. 1975 A consideration of the significance of $\mathrm{C}-14$ discharges from the nuclear power industry. In First, M. W., ed., Proceedings of the 13th AEC Air Cleaning Conference. US Atomic Energy Commission Report CONF740807. Springfield, Virginia, NTIS: 1047-1055.

McCartney, M. (ms.) 1987 Global and local effects of ${ }^{14} \mathrm{C}$ discharges from the nuclear fuel cycle. Ph.D. thesis, University of Glasgow.

McCartney, M., Baxter, M. S., McKay, K. and Scott, E. M. 1986 Global and local effects of ${ }^{14} \mathrm{C}$ discharges from the nuclear fuel cycle. In Stuiver, M. and Kra, R. S., eds., Proceedings of the 12 th International ${ }^{14} \mathrm{C}$ Conference. Radiocarbon 28(2A): 634-643.

McCartney, M., Baxter, M. S. and Scott, E. M. 1988a Carbon-14 discharges from the nuclear fuel cycle: 1 . Global effects. Journal of Environmental Radioactivity 8: 143-155.

1988b Carbon-14 discharges from the nuclear fuel cycle: 2. Local effects. Journal of Environmental Radioactivity 8: 157-171.

McDonald, P., Cook, G. T., Baxter, M. S. and Thomson, J. C. 1990 Radionuclide transfer from Sellafield to South-West Scotland. Journal of Environmental Radioactivity 12(3): 285-298.

Moghissi, A. A. and Carter, M. W. 1977 Global Impact of carbon-14 from nuclear reactors. In Proceedings of the 4th International Congress of the International Radiation Protection Association. Paris, France: 949-951.

NCRP 1985 Carbon-14 in the environment. Recommendations of the National Council on Radiation Protection and Measures. NCRP Report 81.

Pierson, D. H. 1988 Artificial radioactivity in Cumbria: summary of an assessment by measurement and modelling. Journal of Environmental Radioactivity 6: 61-75.

Suess, H. E. 1953 Natural radiocarbon and the rate of exchange of carbon dioxide between the atmosphere and the sea. In Aldrich, W., ed., Proceedings of the 1st Conference on Nuclear Processes in Geologic Settings. Chicago, University of Chicago Press: 52-56.

1955 Radiocarbon concentration in modern wood. Science 122: 415.

Tanaka, N., Monaghan, M. C. and Rye, D. M. 1986 Contribution of metabolic carbon to mollusc and barnacle shell carbonate. Nature 320: 520-523.

Taylor, D. M., Moroni, J. P., Snihs, J.-O. and Richmond, C. R. 1990 The metabolism of ${ }^{3} \mathrm{H}$ and ${ }^{14} \mathrm{C}$ with special reference to radiation protection. Radiation Protection Dosimetry 30(2): 87-93. 